\title{
An Analysis of the Relationship between Christianity and European Humanism from the Perspective of the Image Transformation of Vampires
}

\author{
Ling Xiao ${ }^{1}$, Juan Huang ${ }^{2}$ \\ ${ }^{1}$ Nanchang Hangkong University Science and Technology Institute, Nanchang, Jiangxi , \\ 330034, China; \\ ${ }^{2}$ Nanchang Institute of Technology, Nanchang, Jiangxi,330044, China \\ hunter2011@foxmail.com
}

Keywords: Vampire; image Transformation; Christianity; Humanism

\begin{abstract}
Vampires are monsters in European folklores. Their appearances and image transformation are in the close relationship with Christian doctrine and European humanism. This paper describes and analyzes the different characteristics of the vampire in different stages, and through the image transformation of the vampire from being ugly and horrible to charming reveals the coexistence of and the subtle relationship between religion and humanistic ideas.
\end{abstract}

\section{Introduction}

In the western world, vampires may not be the most sensational among so many demons and ghosts, but they are sure the most appealing. Their images are familiar to the Westerners through the Jewish, Christian legends and so far remain in heat. In the past two thousand years since Christian was introduced to Europe, the images of the vampires have changed many times. Generally speaking, they were turning from ugliness to beauty, from horror to charm, which reflects the changes of status of Christianity in the European Society and its influence on the European humanism.

Shooting in 1994 ,movie Interview with the Vampire, adapted from the vampire novel of the same name by American writer Anne Rice. The protagonists of the film are Hollywood handsome Brad Pitt and Tom Cruise. Their beautiful costumes overturned the vampire image in the minds of audience.

In the eyes of many modern people, vampires should be strong, beautiful and attractive. But the fact is not always so, through the analysis and research of relevant information, it can be found out that the original image of the vampire is not only not beautiful, and even ugly, horrible. To see the original image of the vampire, you have to start from the time of the first vampire superstition.

\section{The Origin and the Image of the Vampire}

The Origin of the Vampire Legend. There are a lot of legends around the world about the bloodsucking fiends. In a Central Asia Persian prehistoric pottery, people found out a picture: a man wrestled blood devil which wanted to suck his blood. This is the first reliable image recorded. In ancient Greek and Roman myths, Gorgon with a snake face, demon Emmpusa with copper foot and bird semi Banshee etc. are also monsters sucking blood and the vitality human. And according to the rabbinical records, before God's creation of Eve, Adam's first wife was Lilith. She and Adam were created with the same clay and after being abandoned by Adam, she became the queen of demons and ghosts. She sucked the baby's blood and let the sleeping young man lose his breath. In 10th Century, there was a record of Lilith in Knowledge of the Division, the biblical Apocrypha.

In the final analysis, the vampire is the product of European civilization, closely related to the religious belief, especially from the Christian religion, which plays a vital role in the formation of the vampire superstition. 
The Change of the Image of the Vampire. In the eyes of the ancient Hebrews, blood is a symbol of life, and a symbol of being unclean and evil. This complex emotions have influenced some later Christ doctrines. "So I say to the children of Israel: 'no matter what is the blood of the living, you can not eat,' said the Old Testament." For the blood of every living creature is his life, and those who eat the blood will be punished "The New Testament also recorded using Jesus's blood to save human beings. Therefore, in the Middle Age Christian world, blood was endowed with supernatural powers.

Although there is no positive recognition of the existence of vampires in the Christian Church, many of its teachings and spirit apparently contributed to the popularity of vampire superstition. If live in violation of doctrine or betrayal of the church after the death of will into a monster that vampires, then it can be inferred that, the first real sense of the vampire, should image is Christian deviate from the ordinary people, they are certainly not beautiful in appearance, they may even be described as very ugly.

(1) Plague Intensifying the Horrible Image of the Vampire. But to the fourteenth century, the vampire superstition in Western Europe was still quite rare. then the great plague of Europe lasting nearly a hundred years made the vampire superstition run out of control. Facing such "Kuangshi terminally ill" with high mortality rate, people became crazy and despair. The faith of religion (mainly Christian) reached its peak. A lot of people thought the spread of the disease was God's punishment to human beings. At this time, the image of the vampire were really terrible, horrible.

When a plague swept Europe in eighteenth Century, many people began to study the problem of the vampire superstition, writing a series of articles. These discussions not only improved the visibility of the vampire, but also made the word "Dracula" (vanpir vampire) to be determined finally and accepted as a common noun.

(2) The Vampire Image in the Literary Boom. But this time the vampire craze quickly retreated. Because the Enlightenment movement launched in Europe, bringing the positive views which were spread gradually. With each passing day of science and technology, many people were beginning to believe that there was no vampire in this world. Hereto and all vampires were changed by the dead people, without any special images. There were unavoidable, ugly, horrible just because of linked with death, disease, apostasy.

Without the subsequent Romanticism literary movement, vampire story might then disappear from the scene. Its arrival not only caused the recovery of the vampire superstition, but also changed the images of the vampires. Vampire became the most popular theme among the Romanticists. British poet Kohler Law supporting the Christabel, Keats's Ruthless Beauty and the Lamia were perfect examples. In poems, vampires were mostly portrayed as beautiful and charming woman who kill. They could also make people feel happiness and death with the victims totally being willing. From then on, the image of the vampire started to become beautiful and charming.

In April 1819. New Issue published The Vampire, medium length novel of John William Polidori in the name of British poet Byron. Since then the vampires have been introduced into the field of prose. Many well-known writers, such as Dickens, Bulwer - Lytton had written this kind of stories. During this period, two very important works were born: Le Fanu's Camilla, and Storck's Dracula. In the book of Camilla, the author describes the heroine, Camilla, the Earl of Karnstein (Millarea von Karnstein), a woman who is full of charm. The book relates to the issue of homosexuality, with an attractive crime suspect, in the revival of the vampire superstition, but also with a metaphor of the sharp problem of human nature. Dracula , published in 1897, is a turning point in the history of literature with vampire superstition. It revived the "Gothic" spirit of the eighteenth century and the vampire superstition making it a modern myth. Under the influence of Romanticism movement, the vampire has become fallen creatures, in pursuit of individual desire with their personality becoming more vivid. Their images had taken on a great change, although still somewhat frightening and strange, but not so ugly like before.

(3)Vampire in Movies. The invention of the film made the image of the vampire more popular, because the vampire films were beginning to be classified as horror movie and the first screen vampires seemed to be more frightening. In 1979, the situation suddenly took a significant change. 
In the American film Stormy, Frankl Langella's Dracula was young, charming and irresistible. From then on, the nature of the vampire movies is no longer limited to horror, the image of vampire in the hearts of the people also began to become more beautiful. Or, until now, people have truly recognized and accepted the beauty of the vampires.

Then, whether in literary works, film or television, the vampires were becoming more and more beautiful and charming. Even if they were in the nature of evil, they would not cause people's fears. The image of the vampire is not always beautiful. Its appearances were turning from being strange, ugly, to more and more beautiful. This is a change worth studying, since few monster can enjoy that kind of treatment. What has caused a series of changes in the image of the vampire? Which of them reflects the human kind of emotional change?

\section{The Relationship between Vampire Culture and Religion}

Vampire genie appeared in ancient myths and legends at a time when humans cherish awe to the unknown and powerful. These monsters have the status similar to a God, so they were of half orcas, or rooted to the Devas with weird and bizarre images, which is closely related to the main form of the primitive religious worship.

As one of three major religions in the world today, Christianity is the most influential and widespread one which had influenced the development of the European history of civilization. Under its influence, the vampire began to leave the original worship of God, the magic of the image of God, and gradually connected with the Christian doctrines. Doctrines and stories recorded in doctrines made people believe that vampire were evil and horrible. People who did not completely follow the doctrine or betrayed, were most likely to become ghosts and vampires. Medieval Europe (6-15 century) was the period with the most powerful Christian forces, " Churches around the Europe were in close connection with the secular politics even more, forming a European political and cultural medieval theocracy characteristics". When the church forces becoming stronger, the doctrine becoming more popular, it was not difficult to understand why the vampire image would be ugly and horrible.

Religion came from the primitive worship of human beings, which expressed the fear and dependence of the unknown and powerful in the early stage of human beings. On the one hand, the religious doctrine ideological constrained people's behavior, warning people to fear God, serve God for God's protection. On the other hand, it also made the society more united, more harmonious. At the time, these teachings played a positive role in social development. But with the continuous progress of human civilization, the doctrine had been behind the pace of the times and even restricted the development of society. In the long run, of course, people desired to break the bondage, becoming more powerful.

The European Renaissance movement, which began in the late fourteenth Century, has brought Humanism to the West. The core of humanistic spirit is to emphasize the value of human, and to oppose the religious doctrine, and the theology which has raised the God and lowered the people. Real vampires prototype is against religious teachings, not being recognized by the church, in which reflects the individual will, unwilling to be bound theocratic rebellious spirit, that precisely fit the core of humanism. The continuous development of this kind of thought embodies the awakening of human consciousness. When it was found in the process of social development, as a person is far greater than God's, naturally people will be lifted to the supreme position and want to be off God's constraints. Vampires are no longer sinners in the eyes of the humanist, instead, they are more willing to beautify them, making them more powerful, and even being able to fight against god. Vampires can become beautiful, due to humanists provocation against theocracy rather than the literary movement of Romanticism

Especially after the mankind entering the 20th century, obtaining achievements comparable with the miracles recorded in religious, humans have became more confident and irreverent of God more than before. However, although there is a contradiction between religion and humanism, they are indispensable power at different stages of the development of human society. Their emergence, existence and opposition are the inevitable result of the development of human society. Today, 
although there have been much less religious forces than before, the role of the past also having a great change in the past, it will still be in existence during a certain range of long-term at this stage. The very change of the image of the vampire is caused by the coexistence and opposition. It reflects not only the delicate relationship between Christianity and European humanism, but also hints to the relationship between religion and humanism in the world.

\section{Conclusion}

Vampire though is the legend of the ghost of Europe in the middle ages, the humanists gave the new life to it. with the transformation of vampire images, they showed a strong desire hidden in the depths of the human heart that is to become more powerful, beyond the gods, controlling everything.

\section{References}

[1] Pocket Bible. Thomas Nelson. Thomas Nelson .2007.6

[2] Mark Lilla.The Stillborn GOD:Religon,Politics,and the Modern West; 2010.2

[3] Berens.E.M. The Myths and Legends of Aneient Greece and Rome 2009.5.

[4] The Vampire Diaries: The Struggle. HarperCollins; Reissue .2010.4.1

[5] The Vampire Diaries. L.J.Smith. Chicago: HarperTeen; Mti 2009.9.1

[6] Holy Bible Random HouseIvy Books 1991-08. 1996.

[7] http://wenku.baidu.com/ 